\title{
SPATIAL VARIABILITY OF STREAMBED VERTICAL HYDRAULIC CONDUCTIVITY AND ITS RELATION WITH STREAM MORPHOLOGIES, CASE STUDY: ZIYARAT RIVER, GOLESTAN PROVINCE, IRAN
}

\author{
BORNA, M. R. ${ }^{1}-$ JAVID, A. H. $.^{2 *}-$ SADEGHIAN, M. S. ${ }^{1}-$ MIRBAGHERI, S. A. ${ }^{3}$ \\ ${ }^{I}$ Department of Civil Engineering, Faculty of Engineering, Tehran Central Branch, Islamic \\ Azad University, Tehran, Iran \\ ${ }^{2}$ Department of Environmental Engineering, Graduate School of Natural Resources and \\ Environment, Science and Research Branch, Islamic Azad University, Tehran, Iran \\ ${ }^{3}$ Civil and Environmental Engineering Faculty, Khaje Nasir Toosi University of Technology, \\ Tehran, Iran \\ *Corresponding author \\ e-mail: a.javid@srbiau.ac.ir; phone:+98-912-103-7369; Fax:+98-214-486-5010
}

(Received $18^{\text {th }}$ Feb 2018; accepted $18^{\text {th }}$ May 2018)

\begin{abstract}
Streambed vertical hydraulic conductivity $\left(\mathrm{K}_{v}\right)$ is a key parameter in the analysis of interactions between streams and aquifers, and that of stream ecosystems. However, the relationship between streambed hydraulic conductivity and stream morphologies has remained untouched. An in-situ standpipe permeameter test method was used to determine the spatial variability in streambed $\mathrm{K}_{\mathrm{v}}$ measured along 36 $\mathrm{km}$ of stream reach in Ziyarat River, Golestan Province, Iran. To triangulate the data and obtain more reliable results, both rising and falling head methods were used. There was great spatial variability in $K_{v}$ among the six test reaches and three $\mathrm{K}_{\mathrm{v}}$ distribution patterns have been accomplished. Test locations in meandering reaches showed a more heterogeneous distribution of vertical hydraulic conductivity than what was observed in straight reaches. The difference in the $\mathrm{K}_{\mathrm{v}}$ of data obtained from meandering reaches was greater than that of the straight reaches which is an indication of a change in the morphology of the river in these reaches due to the erosion and deposition. In other words, morphologic changes of the river in meandering reaches caused evident changes in the streambed which, eventually, caused the erosion and deposition of sediments.
\end{abstract}

Keywords: erosion and deposition, groundwater/surface-water relations, geomorphology, hypoheic zone, Iran, geomorphology

\section{Introduction}

Precise measurement of streambed hydraulic conductivity $\left(\mathrm{K}_{\mathrm{v}}\right)$ is crucial in analyzing the magnitude and extent of water exchange and contaminant transfer between surface water and groundwater. It is even important when coping with a number of geotechnical problems involving the management of groundwater and surface water (Cardenas et al., 2004; Chen et al., 2008; Song et al., 2009; Sebok et al., 2014).

In-stream, the slug test, and the seepage meter coupled with hydraulic gradient measurement, have been widely used. The slug test quantifies only the horizontal hydraulic conductivity. However, it could be employed to specify the permeability of the deeper sediment layer (Chen, 2004; Cheng et al., 2011). The streambed vertical hydraulic conductivity $\left(\mathrm{K}_{\mathrm{v}}\right)$ is known to constantly vary spatially. It has been found by some studies that the $\mathrm{K}_{\mathrm{v}}$ varies greatly along a river transect (Chen, 2005; Min et al., 2013). 
In the analysis of the hydraulic relationship between streams and aquifers, the channel morphologic features are key considered as important (Sebok et al., 2014). Variable pressure heads control Hyporheic interaction in the streambed sediments as well as its environmental conditions (Koch et al., 2011).

The interaction of streams and aquifers can be improved by means of growth of meander length and can be decreased by a reduction in river sinuosity (Boano et al., 2006). Because of the transport of fine materials, the hydraulic conductivity of shallow alluvial aquifers under condition of sinuosity-driven hyporheic flow is not fixed (Nowinski et al., 2011). A meandering stream is one of the key sedimentological forms that links the regional aquifers to the streams (Dong et al., 2012). Sebok et al. (2014) showed that there are more variable streambed characteristics in the meandering than in the straight section. The existence of several orders of magnitude in the range of streambed anisotropy values has been seen close to stream banks (Sebok et al., 2013). The water exchange in the main channel can move into slower pools by anabranch diversions, and enhances the exchange process into the subsurface (Koch et al., 2011). A study which combined the $\mathrm{K}_{\mathrm{v}}$ and erosion and deposition processes of streambed sediments has been conducted by Genereux et al. (2008) and Levy et al. (2011).

(Jiang et al., 2015) A few studies were conducted on the Biloo River in Shanghai, China in four sites and three different morphologies of hydraulic conductivity $\left(\mathrm{K}_{\mathrm{v}}\right)$. The data were limited to a small area of the river - around 40 to $50 \mathrm{~m}$ of the river which were either straight or meandering. In this study, larger reaches were selected to gain more reliable results. For instance, several bends existed in a meandering reach. To better understand the morphologic effects of the river on the hydraulic conductivity $\left(\mathrm{K}_{\mathrm{v}}\right)$ of the streambed, the reaches were selected from three parts of the river: upstream, midstream, and downstream. This was done in order to investigate reaches that represent all parts of the river.

In another research conducted by Lopez et al. (2015), the scholars have gathered over 50 samples from Wadi Khulays dune field, located in western Saudi Arabia, while they also measured the parameters, including grain size distribution, porosity and hydraulic conductivity. They attempted to modify the Beyer equation by adding a parameter linked to the mud concentration and for quantifying the fitting parameter, an inverse optimization process was applied. The obtained equation was promising in predicting the saturated hydraulic conductivity, as its estimations present the lowest error of any empirical equation.

Previous studies recommended that there are many effects on hydraulic conductivity such as stream morphology and geomorphology attributes, river- bed forms, erosion and deposition process, and the riverbed sediments. The knowledge of the streambed hydraulic conductivity for different stream mmrophologies relatively is, however, scarce. The present study investigates the spatial variability in streambed $\mathrm{K}_{\mathrm{v}}$ spanning $36 \mathrm{~km}$ of stream reach in the Ziyarat River, Golestan Province, Iran. An in-situ field standpipe permeameter was utilized to collect 189 total measurements using 6 test sites in 2 stream morphologies: one in the straight stream channel and one in meander reach. All sediment samples were collected after the $\mathrm{K}_{\mathrm{v}}$ tests and they were used for grain-size analysis.

This study had three objectives: (1) investigating the hydraulic conductivity $\left(\mathrm{K}_{\mathrm{v}}\right)$ of the streambed from upstream to downstream; (2) finding the morphologic effects of the river, including the meandering and straight forms, on the hydraulic conductivity $\left(\mathrm{K}_{\mathrm{v}}\right)$ of the river from upstream to downstream; and (3) analyzing the sediment grain size in 
straight and meandering reaches and examining the relationship between sediment grain size and hydraulic conductivity $\left(\mathrm{K}_{\mathrm{v}}\right)$. (4) Finding the best empirical methods used to estimate hydraulic conductivity based on the grain-size distribution.

\section{Materials and methods}

\section{Study area}

Ziyarat River, originating from Alborz mountain range, is located in Golestan Province, which is a northeastern area in Iran. It flows to the north and after $36 \mathrm{kms}$, merges into Gharesoo River. The drainage basin in upstream is about $100 \mathrm{~km}^{2}$ with dimensions of $19.64 \mathrm{~km}$ in length and $5.11 \mathrm{~km}$ in width. The mean of water abstraction rate at stream gauge is about $10.5 \mathrm{~m}^{2}$. The selected six reaches were all covered by these three categories (Fig. 1). The study area is located in a temperate climate. The mean of annual precipitation is equal to $601 \mathrm{~mm}$, and mean temperature is $13.4{ }^{\circ} \mathrm{C}$. The variation in seasonal precipitation is distinctive and not uniform. The temperature of stream water ranges from 19.04 to $29.2{ }^{\circ} \mathrm{C}$. Although, the weather is rainier in winter, the majority of floods occur from August to November. The streambed sediments were alluvial coarse, sand-gravel, and clay and silt in downstream. The highest height of Ziyarat stream gauge is $3068 \mathrm{~m}$ and the beginning of main river is $2620 \mathrm{~m}$. The length of the river to Naharkhoran is $21 \mathrm{~km}$ with the slop average rate of $10.1 \%$ and the remainder of river to Ghorbanabad is $15 \mathrm{~km}$ with the slop average rate of $4.6 \%$.
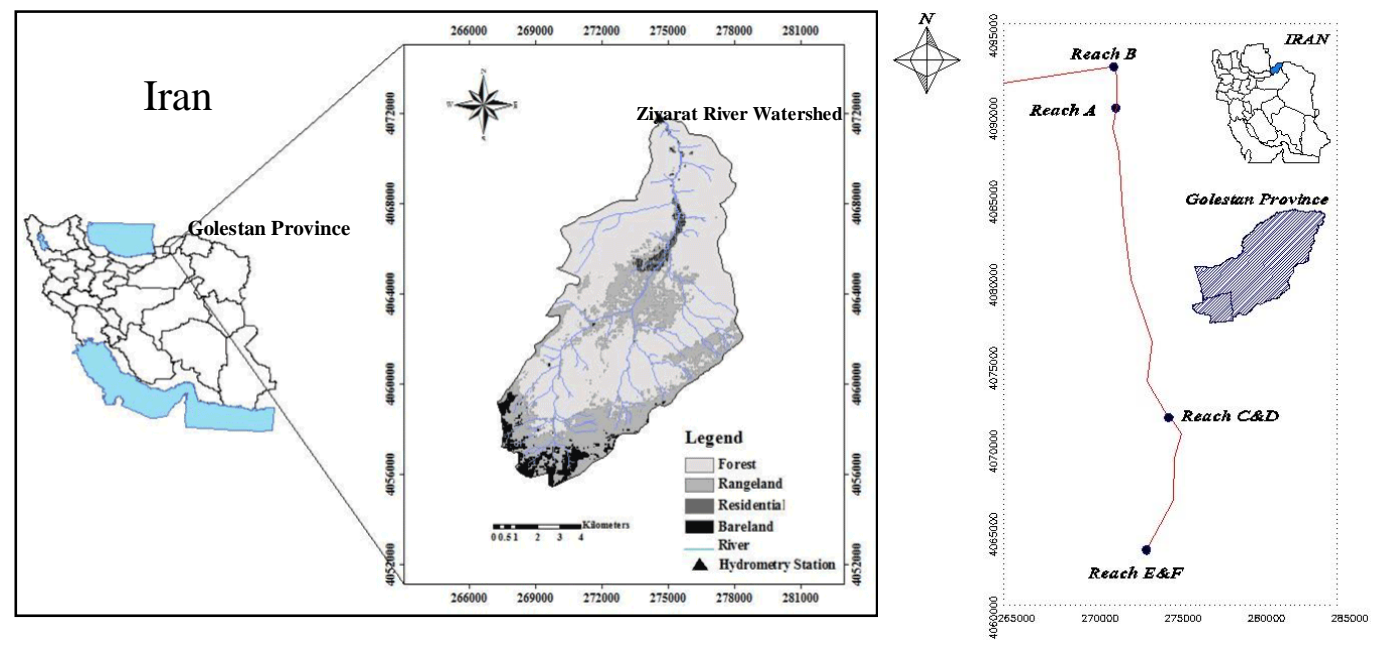

Figure 1. The location of the study area along the Ziyarat River

\section{Reach selection}

The basis of the triple division follows Leopold and Wolman (1957) which, arbitrarily, identified the rivers with a bend coefficient (sinuosity index) larger than 1.5 as meandering and the ones with a bend coefficient lower than 1.5 as straight rivers. We first explain how reaches were determined in this study and then discuss the way we divided each reach into straight and meandering forms.

For each reach, the following field protocol was used to estimate reach hydraulic conductivity using point measurements (Datry et al., 2014). The length of the reach was around 200 to $220 \mathrm{~m}$ and, then, each reach was divided into 10 equal parts using the 11 
transverse sections which had a distance of twice the size of the wetted width from each other. The hydraulic conductivity is obtained from three parts of these 11 sections: the left, center and left sides.

As mentioned above, the straight reach was determined by the sinuosity index which is varied between 1 and 1.5. In addition, the meandering reach was identified by using a sinuosity index of 3 to 4.5 (Gordon et al., 2004). Six reaches were selected in this study: two from the upstream, two from midstream, and two from downstream (Table 1). To better investigate the relationship between the hydraulic conductivity and morphology of the river, the selected reaches were straight and meandering. Therefore, in the upstream, one reach is straight and one is meandering. The same can be applied to the reaches in the midstream and downstream.

Table 1. Hydrological condition and geomorphologies of test reaches

\begin{tabular}{|c|c|c|c|c|c|c|}
\hline & Reach A & Reach B & Reach C & Reach D & Reach E & Reach F \\
\hline Reach name & $\begin{array}{c}\text { Ghorbanabad } \\
\text { straight }\end{array}$ & $\begin{array}{c}\text { Ghorbanabad } \\
\text { Meander }\end{array}$ & $\begin{array}{c}\text { Neharkhoran } \\
\text { Straight }\end{array}$ & $\begin{array}{c}\text { Neharkhoran } \\
\text { Meander }\end{array}$ & $\begin{array}{l}\text { Ziyarat } \\
\text { straight }\end{array}$ & $\begin{array}{l}\text { Ziyarat } \\
\text { Meander }\end{array}$ \\
\hline Test date & May 27, 2018 & May 28, 2018 & May 29, 2018 & May 30, 2018 & May 31, 2018 & June 1, 2018 \\
\hline $\begin{array}{l}\text { End point } \\
\mathrm{UTM}(\mathrm{X}, \mathrm{Y})\end{array}$ & $\begin{array}{l}(271764, \\
4090027)\end{array}$ & $\begin{array}{l}(272887, \\
4092667)\end{array}$ & $\begin{array}{l}(274756, \\
4071500)\end{array}$ & $\begin{array}{l}(274925, \\
4071368)\end{array}$ & $\begin{array}{l}(273662, \\
4063515)\end{array}$ & $\begin{array}{l}(273556, \\
4063317)\end{array}$ \\
\hline $\begin{array}{l}\text { Reach length } \\
\text { (m) }\end{array}$ & 200 & 220 & 200 & 200 & 200 & 200 \\
\hline $\begin{array}{c}\text { Number of } \\
\text { measurement }\end{array}$ & 33 & 33 & 33 & 33 & 33 & 33 \\
\hline $\begin{array}{l}\text { Number of } \\
\text { sediments } \\
\text { sampling }\end{array}$ & 9 & 9 & 9 & 9 & 9 & 9 \\
\hline $\begin{array}{c}\text { Average } \\
\text { water depth } \\
(\mathrm{cm})\end{array}$ & 46.8 & 28.3 & 14.4 & 13.9 & 13.5 & 13.6 \\
\hline $\begin{array}{l}\text { Stream } \\
\text { gradient } \\
(\mathrm{m} / \mathrm{m})\end{array}$ & $0.9 \%$ & $0.49 \%$ & $4.25 \%$ & $4.18 \%$ & $5.74 \%$ & $6.9 \%$ \\
\hline $\begin{array}{c}\text { Average } \\
\text { thickness of } \\
\text { measured } \\
\text { sediment }(\mathrm{cm})\end{array}$ & 44 & 43 & 39.5 & 39 & 38 & 38.5 \\
\hline $\begin{array}{c}\text { Reach } \\
\text { description }\end{array}$ & $\begin{array}{c}\text { Streambed } \\
\text { sediment } \\
\text { contains } \\
\text { medium sand, } \\
\text { silt and clay } \\
\text { particles }\end{array}$ & $\begin{array}{l}\text { Streambed } \\
\text { sediment } \\
\text { contains silt } \\
\text { and clay } \\
\text { articles }\end{array}$ & $\begin{array}{c}\text { Streambed } \\
\text { sediment } \\
\text { contains large } \\
\text { part of sand, } \\
\text { coarse silt and } \\
\text { a small part of } \\
\text { gravel }\end{array}$ & $\begin{array}{c}\text { Streambed } \\
\text { sediment } \\
\text { contains large } \\
\text { part of sand } \\
\text { and a small } \\
\text { part of gravel }\end{array}$ & $\begin{array}{c}\text { Streambed } \\
\text { sediment } \\
\text { contains large } \\
\text { part of sand } \\
\text { and a small } \\
\text { part of gravel }\end{array}$ & $\begin{array}{c}\text { Streambed } \\
\text { sediment } \\
\text { contains large } \\
\text { part of sand } \\
\text { and a small } \\
\text { part of gravel }\end{array}$ \\
\hline
\end{tabular}

\section{Vertical hydraulic conductivity}

A falling-head test is conducted by rapidly raising the water level in the control well and subsequently measuring the falling water level. Slug-in test is another term for falling-head test. A field permeameter method has been adopted for measuring vertical hydraulic conductivity in previous studies (see e.g. Genereux et al., 2008; Song et al., 
2010; Dong et al., 2012). The purpose of this method is to determine the streambed hydraulic conductivity $\left(\mathrm{K}_{\mathrm{v}}\right)$, and as it is illustrated in Figure 2, it operates by vertically inserting a pipe into the streambed, filling the pipe with water, and calculating the amount of decline of the water level inside the pipe. After repeating this process for a few times, the $\mathrm{K}_{\mathrm{v}}$ can be measured using this rate. In the present study, steel standpipe with an inner diameter of $4.8 \mathrm{~cm}$ and length of $120 \mathrm{~cm}$ was used. The pipe was injected into the sediments of the streambed and ensured that the length of the sediment column was nearly equal to $40 \mathrm{~cm}$. A sensor (Onset HOBO Water Level-U20L-Series) with an accuracy of $1 \mathrm{~mm}$ was also employed to measure the water levels. Water was added during the test at the top of the pipe to create a hydraulic head. Then, the head was passed to fall in the pipe. In the current research, a water-level declining interval of $1 \mathrm{~cm}$ was used to record the hydraulic head and time. The hydraulic head estimations were obtained more than 3 times.

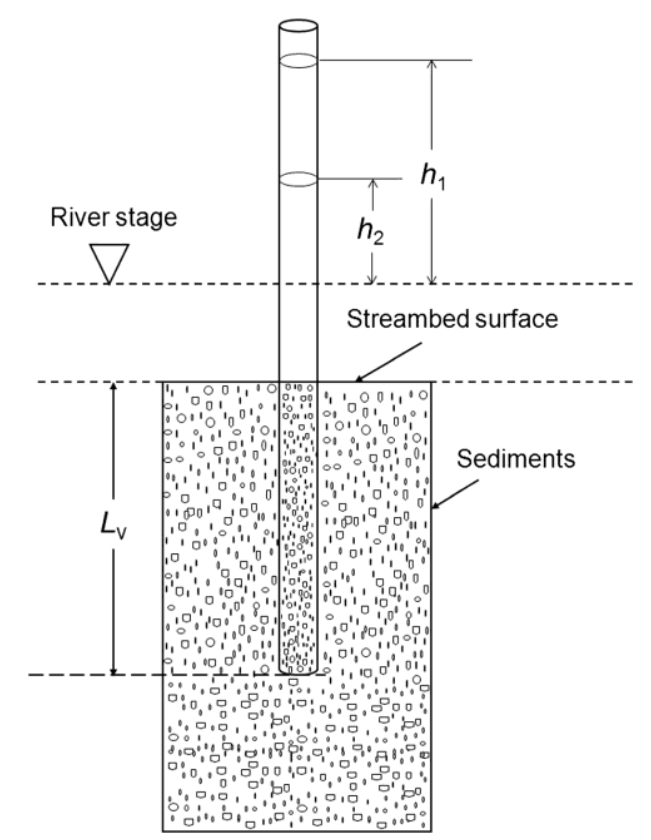

Figure 2. Schematic diagram showing an in situ permeameter test to determine streambed

To measure the $K_{v}$ value using the equation proposed by Hvorslev (1951), all pairs of measured data of hydraulic head and time were used based on Equation 1.

$$
K_{v}=\frac{\frac{\pi D}{11 m}+L_{v}}{t_{2}-t_{1}} \ln \left(h_{1} / h_{2}\right)
$$

where $\mathrm{D}$ denotes the inner diameter of the pipe, $\mathrm{m}$ denotes the square root of the ratio of the horizontal conductivity $K_{h}$ represents the vertical conductivity $K_{v}$ (i.e., $m=\sqrt{\frac{\sqrt[K h]{K V}}{K V}}$, $L_{v}$ refers to the length of the sediment column, $h_{1}$ and $h_{2}$ are hydraulic head inside the pipe measured at times $t_{1}$ and $t_{2}$, respectively. Overall, $K_{h}$ is greater than $K_{v}$. An adapted Hvorslev solution has been proposed by Chen (2004) and Song et al. (2009) in order to specify the $K_{v}$ when $L_{v}$ is greater than D: 


$$
K_{v}=\frac{L_{w}}{t_{2}-t_{1}} \ln \left(h_{1} / h_{2}\right)
$$

However, the error in $\mathrm{K}_{\mathrm{v}}$ from the formula provided by the adapted Hvorslev equation $(E q .2)$ is connected to the ratio $\left(\mathrm{L}_{\mathrm{v}} / \mathrm{D}\right)$ of the estimated sediment length $\left(\mathrm{L}_{\mathrm{v}}\right)$ to the inner diameter (D) of the steel pipe. When $1<\mathrm{m}<5$, if the ratio $\left(\mathrm{L}_{\mathrm{v}} / \mathrm{D}\right)$ is greater than 5, the error of the adapted estimation will be less than 5\% (Chen, 2004).

Moreover, to triangulate the data, the rising-head method was used. A rising-head test is initiated by rapidly lowering the water level in the control standpipe and then taking measurements of the rising water level in the standpipe. The Pneumatic Hi-K Slug provides high-quality data for accurate slug testing of hydraulic conductivity $\left(\mathrm{K}_{\mathrm{v}}\right)$ (Fig. 3).

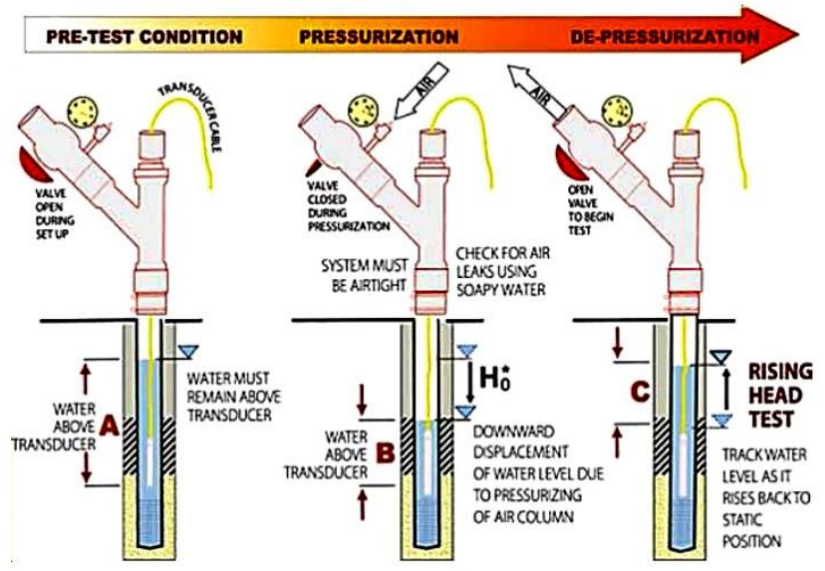

Figure 3. Anatomy of the pneumatic slug test

The following instruments were used: Pneumatic 'HI-K' SLUG from Midwest GEOSCIENCES group, Onset HOBO Water Level-U20L-Series, and Universal OpticUSB Base Station.

The experiment was once accomplished using the falling-head method and once using the rising head. Finally, the values of hydraulic conductivity obtained from these two methods were compared and in the cases where there were significant differences, the $\mathrm{K}_{\mathrm{v}}$ obtained from the rising-head method was retained. The method of KGS and BOWER was employed particularly for the up and midstream where the $\mathrm{K}_{\mathrm{v}}$ was high.

\section{Sediments sampling}

Due to limitations in analyzing grain size of sediments for all the 189 data, we decided to delimit the sampling from the streambed for each reach to 9 samples using systematic sampling. In other words, 54 samples from six reached were chosen. Indeed, the nine samples opted (Table 1) for sediment sampling were a portion of the 33 points which were measured (Fig. 4)

Three points which were selected for each reach were obtained from the middle, right, and left sides (transverse). These three points were located at the beginning, in the middle and at the end of each reach. 
Hand Operated Auger instrument was used to sample and transfer undisturbed sediments. Due to sediments resistance and coarseness, common instruments could not properly enter streambed sediments and, particularly, seal. This justifies our employed instrument in this study that was used in hyporheic zone $(40-45 \mathrm{~cm}$ bellow the river surface). As a result, this led the whole auger to move into streambed sediments. Eventually, the samples were sent to Golestan Province soil mechanic laboratory. Moreover, for measuring hydraulic conductivity based on particle-size distribution (PSD), the 54 sets of soil samples were collected. To estimate particle size distribution (grain size curve), AASHTO-T27 method was applied. The finest sieve size was $0.075 \mathrm{~mm}$ and the largest one was $9.5 \mathrm{~mm}$. Particle size $<0.075 \mathrm{~mm}$ was grouped into silt and clay, particle size between $0.075-2.0 \mathrm{~mm}$ into sand, and particle size $>2.0 \mathrm{~mm}$ into gravel (Song et al., 2010).

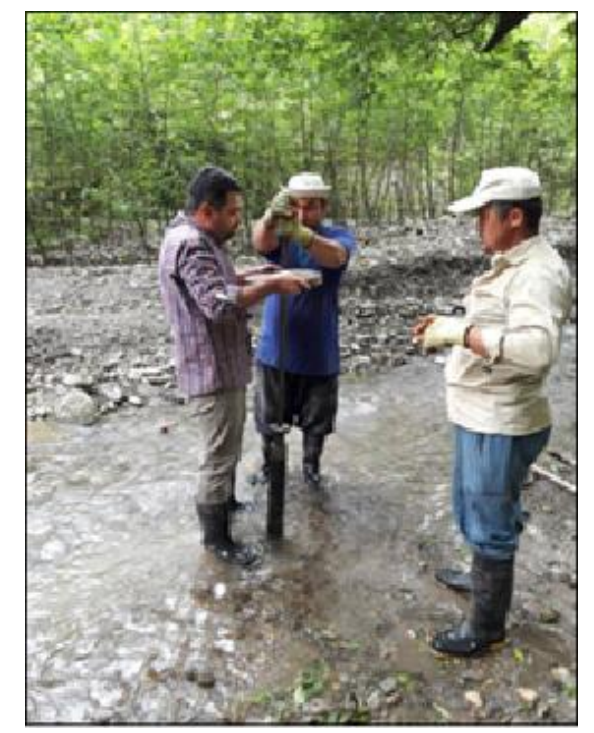

Figure 4. Principle of the sediment sampling method

\section{Normality test}

A Kolmogorov-Smirnov test was employed to check whether the distribution of the data was normal or not. This test was conducted using SPSS version 22.0. If $p<.05$, it rejects the null hypothesis that the $\mathrm{K}_{\mathrm{v}}$ value does not belong to the normal or lognormal distribution. However, it accepts that the $\mathrm{K}_{\mathrm{v}}$ values belong to the normal distribution if $p>.05$.

The results, as displayed in Table 2, showed that the values for reach $\mathrm{B}$ did not have a normal distribution while the reaches of $\mathrm{A}, \mathrm{D}$, and $\mathrm{F}$ had a normal distribution. In addition, the reaches of $\mathrm{C}$ and $\mathrm{E}$ were not normally distributed although their values were close to the significance level for normality. All the 189 data were not normally distributed as indicated by the Kolmogorov-Smirnov test. However, when they were classified into reaches, the results indicated that some of them were normal.

As the extracted data for $\mathrm{K}_{\mathrm{v}}$ were in the quantitative form (Ratio Data) and their distribution was approximately normal, while the number of these samples was greater than any other group (33 samples from each group) and only a quantitative variable of six groups was compared with each other, hence we used One-Way ANOVA to 
compare the mean of the data at different reaches. First, a comparison was made between the groups in term of variance, so called Test of homogeneity of variance and it was observed that the associated variances were not identical $(\mathrm{P}<0.05)$. Therefore, unequal variances tests were used for making a comparison between the mean of six groups; for this purpose, Dunnett tests were utilized. As a result, the obtained significance level was equal to $\mathrm{P}<0.05$, hence the $\mathrm{H}_{0}$ hypothesis was rejected, while $\mathrm{H}_{1}$ hypothesis was confirmed with $95 \%$ confidence, implying that there is a significant difference between the $\mathrm{K}_{\mathrm{v}}$ mean for six reaches level.

Table 2. Results of the Kolmogorov-Smirnov test for the six reaches

\begin{tabular}{c|c|c}
\hline Test site & $\begin{array}{c}\text { Kolmogorov-Smirnov Test } \\
\text { Sig. }\end{array}$ & Number of data \\
\hline Reach A & 0.2 & 33 \\
\hline Reach B & 0.000 & 33 \\
\hline Reach C & 0.047 & 33 \\
\hline Reach D & 0.2 & 33 \\
\hline Reach E & 0.048 & 33 \\
\hline Reach F & 0.102 & 33 \\
\hline
\end{tabular}

Therefore, the six reaches were analyzed through one-way ANOVA. Table 3 shows that there was not any significant difference between the reaches of C and D. Similarly, no significant difference was observed between the reaches of $\mathrm{E}$ and $\mathrm{F}$. The correlations between the other reaches were, however, significant.

Table 3. Result of one-way ANOVA for comparing six reaches

\begin{tabular}{|c|c|c|c|c|c|c|}
\hline & Reach A & Reach B & Reach C & Reach D & Reach E & Reach F \\
\hline Reach A & ------- & $*$ & $*$ & $*$ & $*$ & $*$ \\
\hline Reach B & & ------- & * & $*$ & $*$ & $*$ \\
\hline Reach C & & & ------- & $\sqrt{ }$ & $*$ & $*$ \\
\hline Reach D & & & & ------- & $*$ & $*$ \\
\hline Reach E & & & & & ------- & $\sqrt{ }$ \\
\hline Reach F & & & & & & ------- \\
\hline
\end{tabular}

\section{Results}

The values of $\mathrm{K}_{\mathrm{v}}$ in the 189 measured data for six reaches of the streambed were between $0.109(\mathrm{~m} / \mathrm{d})$ and $152.37(\mathrm{~m} / \mathrm{d})$. According to Table 4, overall, the highest value of $\mathrm{K}_{\mathrm{v}}$, as expected, was found in the upstream within reach $\mathrm{F}$, which was a meandering type of reach. The least amount of hydraulic conductivity was obtained in downstream in reach $\mathrm{B}$, which is also a meandering type. To better analyze the hydraulic conductivity in these six reaches, $\mathrm{K}_{\mathrm{v}}$ was obtained for 11 intervals which had a distance of $20 \mathrm{~m}$. In fact, in each reach, the $\mathrm{K}_{\mathrm{v}}$ was measured once in the middle of the streambed, once in the right side, and once in the left side of the streambed. Therefore, from each reach of the streambed in the total 11 intervals, 33 data of hydraulic conductivity were obtained. 
Table 4. Statistics for $K_{v}$ values from permeameter tests

\begin{tabular}{c|c|c|c|c|c}
\hline & Range $\mathbf{( m / d )}$ & Mean $(\mathbf{m} / \mathbf{d})$ & Median $(\mathbf{m} / \mathbf{d})$ & Std. error of mean & Std deviation \\
\hline Reach A & $0.245-4.860$ & 1.798 & 1.632 & 0.235 & 1.351 \\
\hline Reach B & $0.109-5.041$ & 0.687 & 0.233 & 0.204 & 1.172 \\
\hline Reach C & $71.48-142.2$ & 104.55 & 105.68 & 2.57 & 14.76 \\
\hline Reach D & $63.56-125.56$ & 102.46 & 103.99 & 2.604 & 14.6 \\
\hline Reach E & $73.76-146.67$ & 118.56 & 122.47 & 3.304 & 18.98 \\
\hline Reach F & $63.01-152.37$ & 118.96 & 122.25 & 3.66 & 21.05 \\
\hline
\end{tabular}

\section{$\operatorname{Reach} A$}

Geographical position of reach A is presented in Table 1 which illustrates that this reach is located in the downstream. This reach has a straight form and since the grains of the sediments in the streambed are tiny, the hydraulic conductivity has been low, within the range of $0.245(\mathrm{~m} / \mathrm{d})$ and $4.86(\mathrm{~m} / \mathrm{d})$, as shown in Table 4 . The distribution of the data was normal, and the results also showed that the mean of $\mathrm{K}_{\mathrm{v}}$ in the middle of the streambed is more than the right or left sides of it as shown in Table 5. In addition, the mean of the data in the middle of the canal is closer to the first quarter.

Table 5. Mean of $K_{v}$ values for three sides test reaches

\begin{tabular}{c|c|c|c}
\hline & $\mathbf{K}_{\mathbf{v}}(\mathbf{l e f t})$ & $\mathbf{K}_{\mathbf{v}}(\mathbf{c e n t e r})$ & $\mathbf{K}_{\mathbf{v}}(\mathbf{r i g h t})$ \\
\hline Reach A & 1.700 & 2.68 & 1.01 \\
\hline Reach B & 1.098 & 0.549 & 0.414 \\
\hline Reach C & 97.79 & 113.75 & 102.11 \\
\hline Reach D & 110.56 & 103.064 & 93.76 \\
\hline Reach E & 114.89 & 127.36 & 113.43 \\
\hline Reach F & 128.68 & 119.40 & 108.81 \\
\hline
\end{tabular}

\section{Reach B}

Reach B which is a meandering type of reach, is located in downstream, as mentioned in Table 1. It was previously highlighted that the $\mathrm{K}_{\mathrm{v}}$ obtained from this reach did not have a normal distribution. Since this reach was in the lower side of the streambed, its range of $K_{v}$ was remarkably such low that it was between $0.109(\mathrm{~m} / \mathrm{d})$ and $5.041(\mathrm{~m} / \mathrm{d})$, and its mean was $0.687(\mathrm{~m} / \mathrm{d})$, as shown in Table 4. As it was illustrated in Figure 5b, the rate of changes to the hydraulic conductivity in the left side of the streambed was more than the middle and right side of it. The grains of the sediments were mostly made of silt and clay which, in some parts, acted like an impermeable layer.

\section{Reach C}

This reach was located in the middle part of the streambed and had a straight form. Its geographical position is described in Table 1 According to Table 4, the range of changes of $\mathrm{K}_{\mathrm{v}}$ is between $71.48(\mathrm{~m} / \mathrm{d})$ and $142.2(\mathrm{~m} / \mathrm{d})$ which shows a permeable layer. Moreover, the median and mean of $\mathrm{K}_{\mathrm{v}}$ data in the middle of the streambed are more 


$$
-3658 \text { - }
$$

than the left and right sides of it (see Figure $5 c$ ). The mean of $\mathrm{K}_{\mathrm{v}}$, as shown in Table 4 , is 104.55 . Although the data were not normal, its distribution was close to normal (see Table 2).

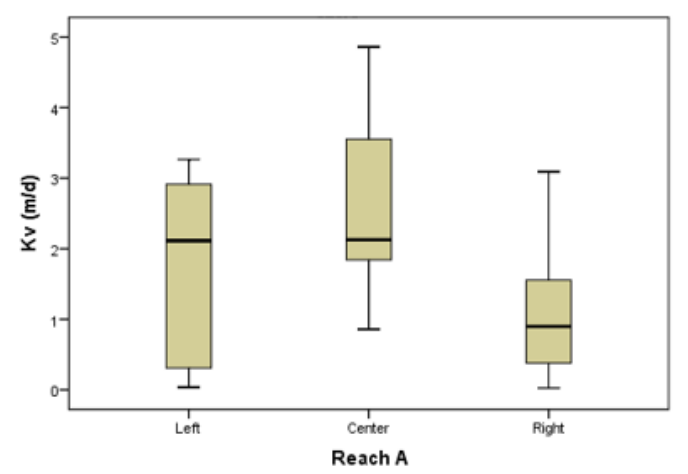

(a)

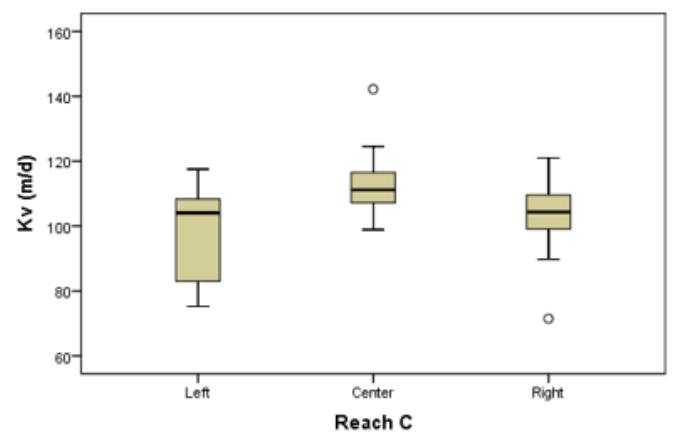

(c)

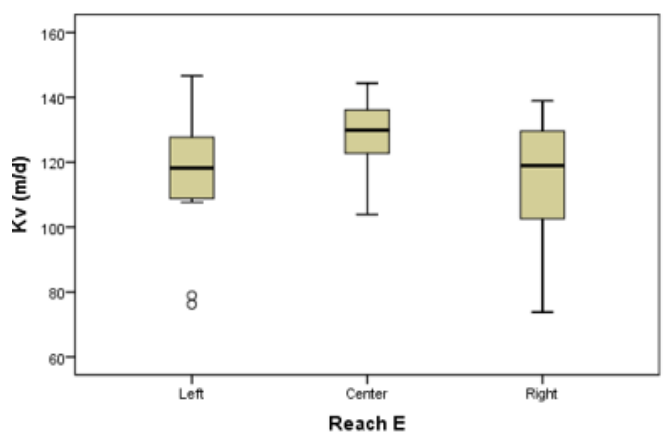

(e)

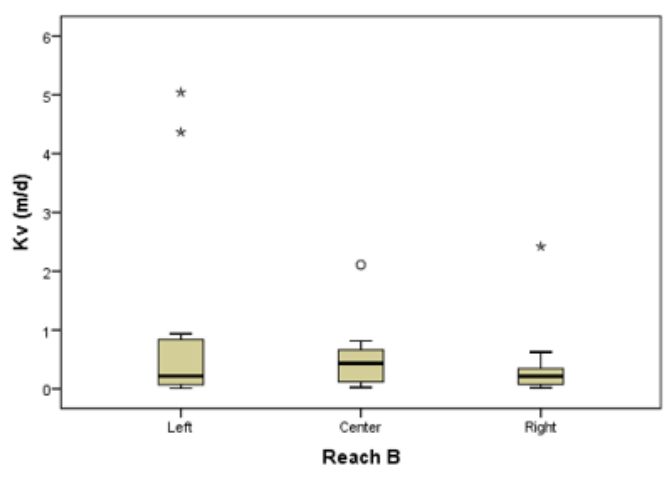

(b)

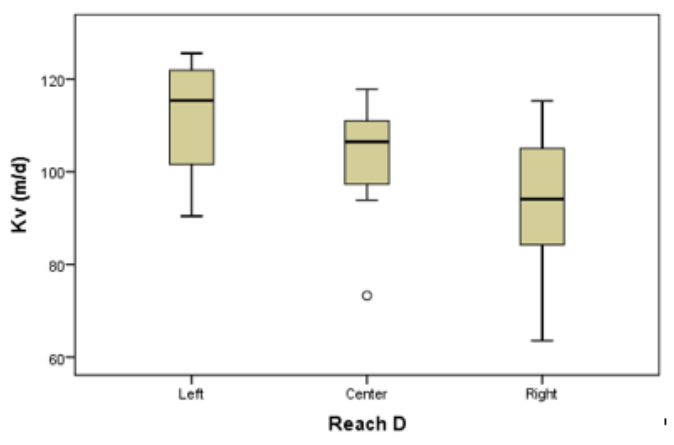

(d)

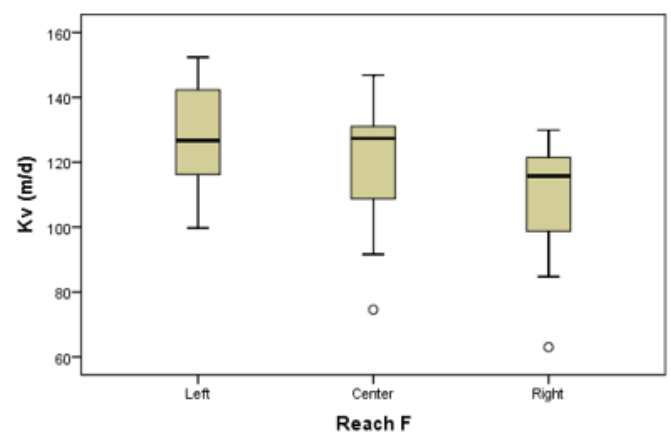

(f)

Figure 5. Box plots of streambed $K_{v}$ for each test reach

\section{Reach D}

This reach, which has a meandering shape, is located at the geographical position of Table 1. The range of $\mathrm{K}_{\mathrm{v}}$, as shown in Table 4, is between $63.56(\mathrm{~m} / \mathrm{d})$ and $125.56(\mathrm{~m} / \mathrm{d})$ and the mean of the $K_{v}$ of the streambed is $102.46(\mathrm{~m} / \mathrm{d})$. In addition, the mean of the $\mathrm{K}_{\mathrm{v}}$ in the left side of the streambed is more than the right side. According to what is shown in 
the box plot, the range of the changes of the $\mathrm{K}_{\mathrm{v}}$ in the right side of the streambed is more than the other two parts. The data were normally distributed, as indicated in Table 2.

\section{Reach $E$}

This reach of the river, which has a straight shape, is located in the upper part of the river. The range of the changes of $\mathrm{K}_{\mathrm{v}}$ (Table 4) is between $73.76(\mathrm{~m} / \mathrm{d})$ and 146.67 $(\mathrm{m} / \mathrm{d})$. Moreover, the $\mathrm{K}_{\mathrm{v}}$ for the riverbed is equal to $118.56(\mathrm{~m} / \mathrm{d})$. The results indicated that the $\mathrm{K}_{\mathrm{v}}$ for the streambed in the middle part of the river is more than the other two parts. The range of the changes in the middle part, however, was less than the other two sides. This range, as displayed in Fig. 5e, has decreased the normality of the data, though they were so close to normality. The plot of frequency (Fig. 6e) shows the normality of the data.

\section{Reach F}

This reach of the river, which has a meandering shape, is located in the upper side of the river and based on Table 1, the range of its changes is between $63.01(\mathrm{~m} / \mathrm{d})$ and $152.37(\mathrm{~m} / \mathrm{d})$ (Table 4). Also, (Table 5)shows that the hydraulic conductivity $\left(\mathrm{K}_{\mathrm{v}}\right)$ in the left side of the river is more than the other two sides. Similarly, the range of hydraulic conductivity in the left side is higher than the middle and right sides of the river (see Fig. 5f). The distribution of the data was also normal, as demonstrated in the frequency plot (see Fig. 6f).

\section{Grain size analysis}

Grain size is the main controlling factor for streambed hydraulic conductivity (Song et al., 2010). After investigating the six reaches, it became evident that the physical features in the downstream and, in particular, the meandering reach (Reach B), were different from the other reaches, as shown in Table 6 . The sediments in the bed of these two reaches (A and B) were completely small and consisted of silt and clay (Table 6).

The average distributions of grain size in sediments are significantly different at each position of the channel at all the tested reaches (Fig. 7).

It becomes evident after comparing the data and distributions of $\mathrm{K}_{\mathrm{v}}$ values (Table 4) collected from In situ permeameter tests at each position $(\mathrm{L} / \mathrm{C} / \mathrm{R})$ at all test reaches that a higher average value of cumulative percentage in weight of silt and clay $(<0.075 \mathrm{~mm})$ is correlated with higher hydraulic conductivity.

According to Table 5, the process of erosion in the left side of the channel is stronger than in the right side. Erosional areas mainly occur in the left towards the central channel which has caused the mean $\mathrm{K}_{\mathrm{v}}$ in the left side of the reach to be more than the right side. Therefore, the mean of the grain size in the left side of the reach is expected to be more than the right side (Fig. $7 b$ ). In fact, in Reach A, the central area has more erosion than the left or right sides, and it is shown that the erosional process increases from the center bank to the right and left banks. The hydraulic conductivity in the middle part of reach $\mathrm{A}$ is more than the other parts and this is directly related to its larger grain size. For better analysis of the 54 sediment samples, obtained from six selected reaches of the entire riverbed, we were obliged to determine the percent of sediments particles size in accordance with Table 6. Table 6 is useful for gaining an insight into the impact of erosion and sedimentation on hydraulic conductivity within 
six reaches, resulted from difference between the morphological properties of the reaches, from upstream till downstream.

Table 6. Sediment grain size distributions for the 54 samples collected

\begin{tabular}{|c|c|c|c|c|c|c|}
\hline \multirow{2}{*}{ Particle size } & \multicolumn{6}{|c|}{ Test reaches } \\
\hline & Reach A & Reach B & Reach C & Reach D & Reach E & Reach F \\
\hline$<2 \mathrm{~mm}$ & 58 & 100 & 40.8 & 47 & 40.8 & 42.1 \\
\hline $\begin{array}{l}\text { Average value of }<0.075 \mathrm{~mm} \\
\text { cumulative percentage } \\
\text { in weight }\end{array}$ & 2.7 & 18 & 1.11 & 2 & 1.12 & 1.4 \\
\hline Average media $\mathrm{d}_{50}(\mathrm{~mm})$ & 1.2 & 0.17 & 3.1 & 2.1 & 3.1 & 2.9 \\
\hline
\end{tabular}

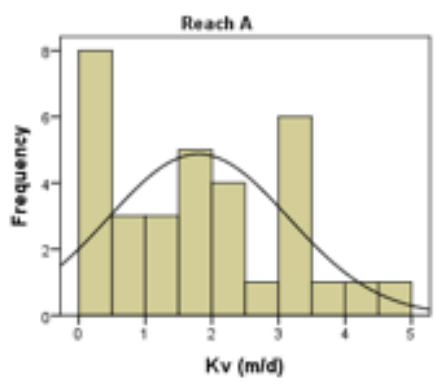

(a)

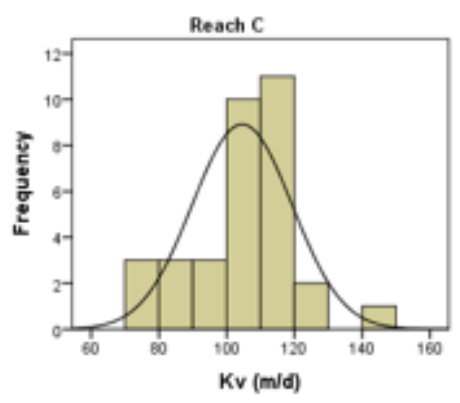

(c)

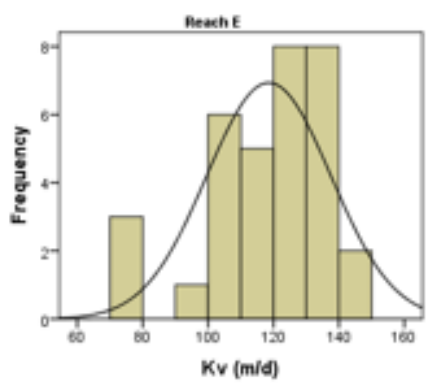

(e)

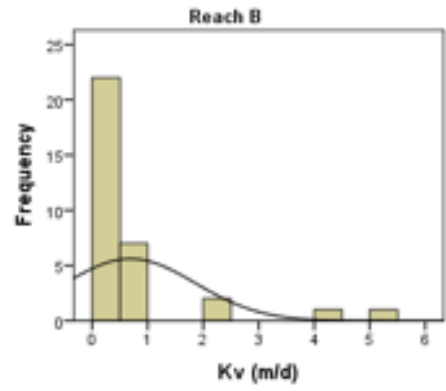

(b)

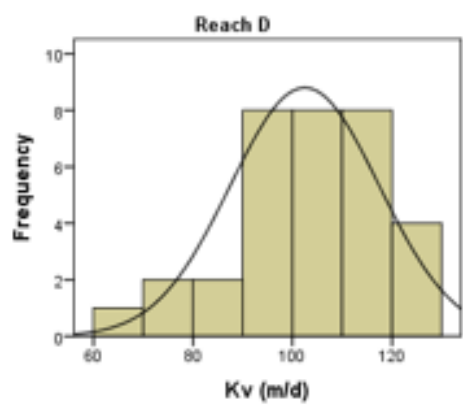

(d)

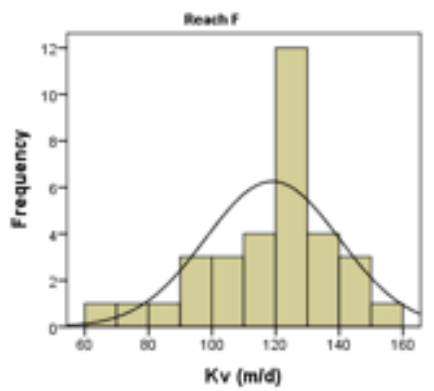

(f)

Figure 6. Histogram of $K_{v}$ values pooled together from each test reach 


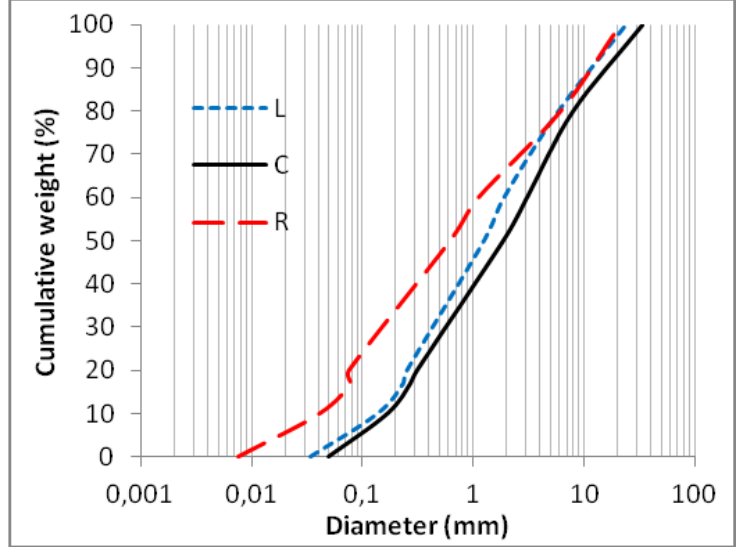

a

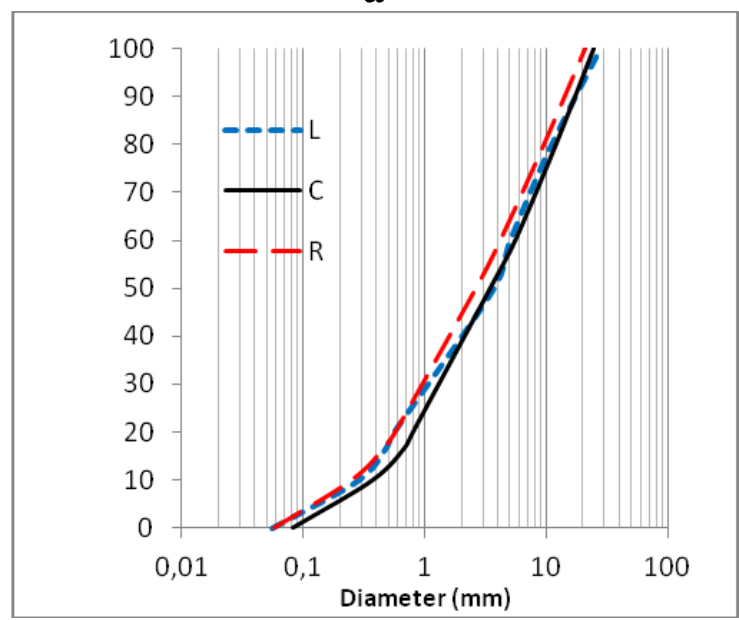

C

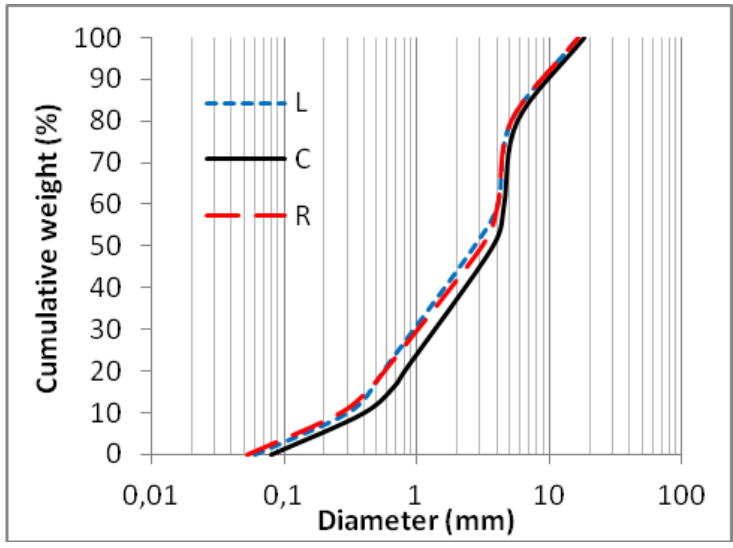

e

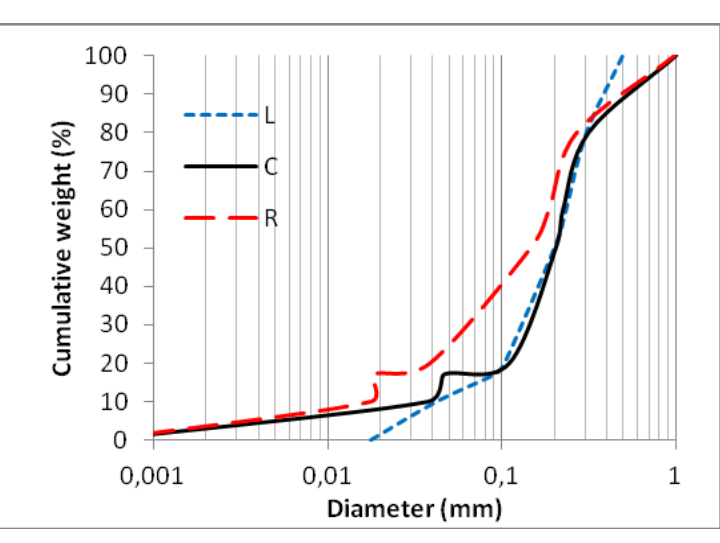

b

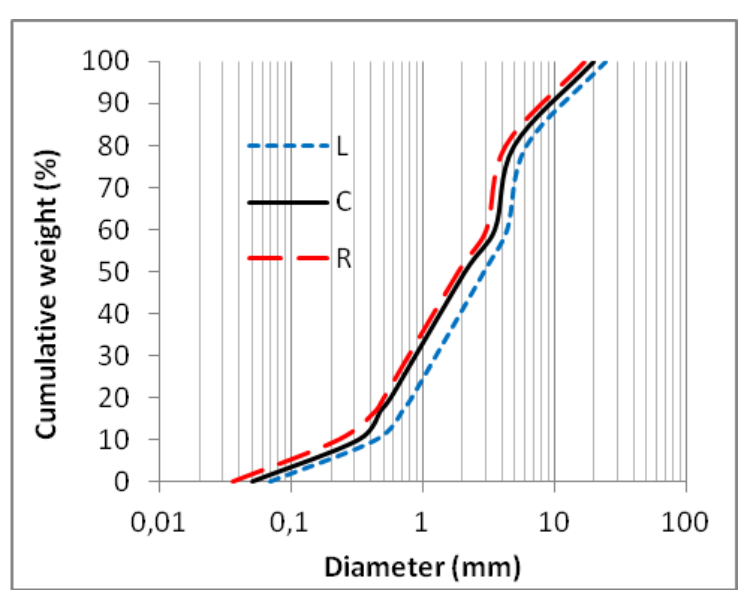

d

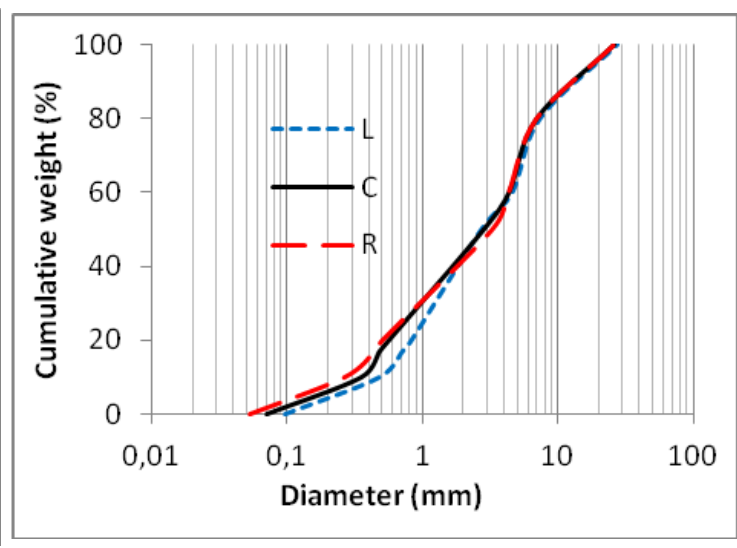

f

Figure 7. Average grain size distributions of streambed from each test reach along the Ziyarat River. a. Straight reach $A, \boldsymbol{b}$. Meandering reach $B$, c. Straight reach $C, \boldsymbol{d}$. Meandering reach D, $\boldsymbol{e}$. Straight reach $C, \boldsymbol{f}$. Meandering reach $F$

This difference can be attributed to the difference between meandering reaches and straight reaches, such that with more erosion in the left parts of the reach due to the curvature of the streambed. This difference affects the grain size of the sediments and, eventually $\mathrm{K}_{\mathrm{v}}$. 
When the particles in the upstream are compared with the ones in the downstream, it becomes evident that the larger grains exist in the upstream and the smaller ones exist in the downstream and even the silt and clay particles $(<0.075 \mathrm{~mm})$ cover the whole river in this part. This could be a reason for the high hydraulic conductivity $\left(\mathrm{K}_{\mathrm{v}}\right)$ in the upstream and a low hydraulic conductivity $\left(\mathrm{K}_{\mathrm{v}}\right)$ in the downstream as well as the impermeability of the streambed in the downstream. To better understand this issue, the correlation between $\mathrm{K}_{\mathrm{v}}$ and $\mathrm{d}_{10}$ was investigated. $\mathrm{d}_{10}$ is the soil particle diameter $(\mathrm{mm})$ such that $10 \%$ of all soil particles are finer (smaller) by weight.

\section{Correlation between $K_{v}$ and grain size}

The statistical analysis of the values of $\mathrm{K}_{\mathrm{v}}$ and the grain size of the sediments in the streambed showed that the $\mathrm{K}_{\mathrm{v}}$ had the highest correlation with $\mathrm{d}_{10}$ and $\mathrm{d}_{60}$.

Where $\mathrm{d}_{10}$ and $\mathrm{d}_{60}$, are the soil particle diameter $(\mathrm{mm})$ that $10 \%$ and $60 \%$ of all soil particles are finer (smaller) by weight.

Pearson correlation analysis was used to verify whether the two normally distributed variables were significantly correlated. However, when all the data from correlation coefficients between grain size and the vertical hydraulic conductivity are taken into account for each test reach. The results showed that the correlation between $\mathrm{K}_{\mathrm{v}}$ and $\mathrm{d}_{10}$ was higher $(r=.906)$ than the one between $\mathrm{K}_{\mathrm{v}}$ and $\mathrm{d}_{60}(r=.0 .748)$. The results for all the test reaches showed that the correlations were significant at $95 \%$ confidence level. The analysis indicated that the significance level was less than 0.05 which is an indication that the two variables were statistically correlated and had a linear correlation.

\section{Empirical methods used to estimate hydraulic conductivity from grain-size distribution}

The available soil properties such as particle-size distribution revealed many different relationships. As shown in Tables 7 and 5 empirical methods; USBR, Shepherd, Hazen, Beyer, Slichter and Kozeny, were selected from Vukovic and Soro (1992) to measure Ks, hydraulic conductivity. The applied parameters are as follow: $\mathrm{g}$ denotes the acceleration of gravity; $v$ denotes the kinematic viscosity for a given temperature; in this study, at $20^{\circ} \mathrm{C}, \mathrm{v}=1.004 \times 10^{-6} \mathrm{~m}^{2} / \mathrm{s}$ (Kasenow, 2002).

$\beta$ represents a dimensionless coefficient, All equations have the porosity (n) function, and $d_{w}$ refers to the effective grain diameter $(\mathrm{mm})$ at $\mathrm{w}$ cumulative weight percentage of smaller grain size. Porosity can be estimated by (Vukovic and Soro, 1992; Kasenow, 2002) $\mathrm{n}=0.255\left(1+0.83^{\mathrm{c}}\right)$, where $\mathrm{c}$ is the coefficient of grain uniformity and is represented by $\mathrm{c}=\mathrm{d}_{60} / \mathrm{d}_{10}$. Here, $\mathrm{d}_{60}$ and $\mathrm{d}_{10}$ are the particle diameters derived from cumulative distribution curves and represent size fractions at which they are equal to $60 \%$ and $10 \%$, respectively, of the sample by weight composed of grains of a smaller size (Ayers et al., 1998).

Results are clearly shown in Figure 8, illustrates the mean score between the obtained Hydraulic conductivity data from empirical formulas and permeameter tests in six reaches from upstream to downstream. It is evident that the mean of these five formulas in first and second reaches from downstream are completely near. Therefore, it indicates that empirical formulas are good predictors for estimating the hydraulic conductivity, especially in fine sediments. 


$$
-3663 \text { - }
$$

Table 7. Methods used to estimate hydraulic conductivity grain size data $(\mathrm{m} / \mathrm{d})$

\begin{tabular}{c|c|c|c|c|c}
\hline Formula & $\boldsymbol{\beta}$ & Equation & $\overline{\mathbf{x}}_{\mathbf{2}}$ & $\overline{\mathbf{x}}_{\mathrm{g}}$ & $\overline{\mathbf{x}}$ \\
\hline USBR & $4.8 \times 10^{-4}$ & $\beta \frac{\mathrm{g}}{\mathrm{v}} \mathrm{d}_{20}^{2.3}$ & 127.67 & 31.31 & 83.37 \\
\hline Shepherd & 142 & $\mathrm{~d}_{50}^{1.65}$ & 141.91 & 45.04 & 174.62 \\
\hline Hazen & $6 \times 10^{-4}$ & $\beta \frac{\mathrm{g}}{\mathrm{v}}[1+10(\mathrm{n}-0.26)] \mathrm{d}_{10}^{2}$ & 42.26 & 11.39 & 35.46 \\
\hline Beyer & $6 \times 10^{-4}$ & $\beta \frac{\mathrm{g}}{\mathrm{v}} \log \left(\frac{500}{\mathrm{c}}\right) \mathrm{d}_{10}^{2}$ & 56.54 & 0.00 & 45.49 \\
\hline Slichter & 0.01 & $\beta \frac{\mathrm{g}}{\mathrm{v}} \mathrm{n}^{\mathrm{a} .287} \times \mathrm{d}_{10}^{2}$ & 8.53 & 2.35 & 6.99 \\
\hline Kozeny & $8.3 \times 10^{-4}$ & $\beta \frac{\mathrm{g}}{\mathrm{v}} \frac{\mathrm{n}^{\mathrm{a}}}{(1-\mathrm{n})^{2}} \times \mathrm{d}_{10}^{2}$ & 19.21 & 5.36 & 15.62 \\
\hline \multicolumn{7}{r}{} & $\mathrm{K}_{\mathrm{v}}$ & & 65.47 & 14.41 & 78.85 \\
\hline
\end{tabular}

Also shown are the arithmetic mean $\overline{\mathrm{x}}_{\mathrm{a}}$, the geometric mean $\overline{\mathrm{x}}_{\mathrm{g}}$ and median hydraulic conductivity $(\tilde{\mathrm{x}})$ calculated by the methods $\mathrm{K}$ values are given in $\mathrm{md}^{-1}$

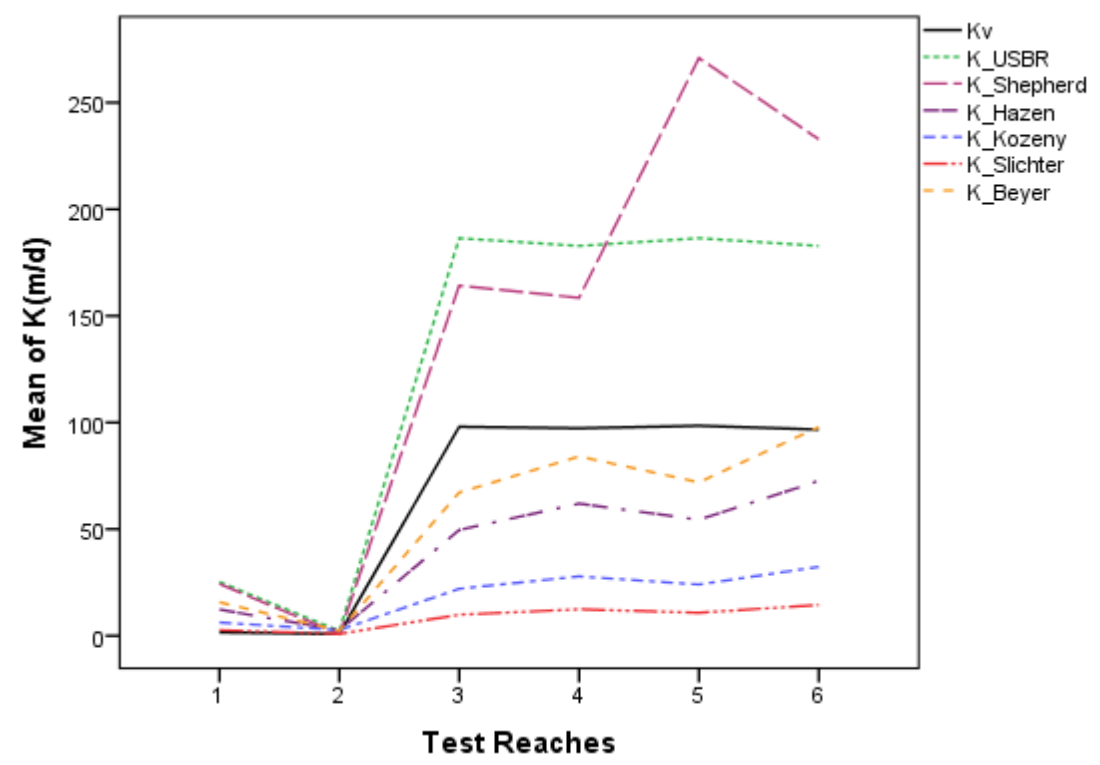

Figure 8. Mean values of $K$ from each of the five empirical grain size methods for these six reaches

We should bear in mind that Table 7 shows the the arithmetic mean $\overline{\mathrm{x}}_{\mathrm{a}}$, the geometric mean $\overline{\mathrm{x}}_{\mathrm{g}}$ and median hydraulic conductivity $(\tilde{\mathrm{x}})$. The obtained medians from USBR formula and permeameter test were closer. Box plot Odong (2007) proved that Kozeny formula is the best estimator. Comparing different formulas, Song et al. (2009) stated that the obtained data from USBR were closer to hydraulic conductivity measured from Falling-Head standpipe method. 


\section{Discussion}

The amount of $\mathrm{K}_{\mathrm{v}}$ in the total 189 samples analyzed in the six reaches was between 0.109 and 152.37. According to Table 4, overall, the highest measured $\mathrm{K}_{\mathrm{v}}$ in the upstream was obtained for reach $\mathrm{F}$ and the lowest range of hydraulic conductivity was measured in downstream in the meandering reach B. In addition, this study shows that in straight reaches, whether in the upstream, midstream, or upstream, the highest $\mathrm{K}_{\mathrm{v}}$ was found in the central part of the river.

In the straight-shaped reaches (see Fig. 7a, c,e), the curve intersection of the right, middle and left sediments with $\mathrm{X}$ axis was close to each other, while in the meandering reaches such difference was evident due to the high potential of the flow in sedimentation, particularly within the left section of the river channel (see Table 5) and this fact leads to a relative increase in the hydraulic conductivity of the mentioned section. That is, the impact of meandering reach properties within $\mathrm{B}, \mathrm{D}$ and $\mathrm{F}$ reaches on the sediment particles transfer led to the lack of a uniform distribution for the particles percentage. The interesting aspect of the difference reaches to its peak in the downstream of the river (see Fig. 7b), where the relative increase in the sedimentation within the right section of the reach and existence of erosion within the left section not only lead to formation of variable percent of silt and clay fine particles, but also these factors lead to formation of an impermeable layer and mitigation in the hydraulic conductivity, as well as they lead to a high mean difference of $\mathrm{K}_{\mathrm{v}}$ between the left and right sections of the river.

The findings of streambed $\mathrm{K}_{\mathrm{v}}$ distribution indicated a large spatial variability for each reach test and grain size in streambed sediments (Song et al., 2010). Sebok et al. (2014) found that the streambed attributes in meandering reaches were more different than in straight ones. The variability of $\mathrm{K}_{\mathrm{v}}$ values was related to the erosion and deposition of streambed sediments, as found in some other studies (e.g. Genereux et al., 2008; Levy et al., 2011).

The results obtained in this research are in line with the afore-mentioned results, but with the innovation in choosing the reaches throughout the river, the effect of meandering and straight reaches on the hydraulic conductivity has been clarified, so that the morphological variation of the river are more evident in the downstream of the river, so that the variation ranges for $\mathrm{K}_{\mathrm{v}}$ are closer at the upstream, even in the meandering reaches, but this case is contrariwise in the downstream section, and changes in the $\mathrm{K}_{\mathrm{v}}$ are obvious.

Regional variations in streambed characteristics, including sedimentary texture and sedimentary structure, have been among other attributes (Min et al., 2013). As a result, the grain size of streambed sediment, which can be related to various types of morphologies, bed forms, and erosional and depositional regimes, is correlated with $\mathrm{K}_{\mathrm{v}}$ values.

With regard to the investigation applied in the present study, it was observed that each test reach has different stream morphology. Reach B, which is a meandering reach, is composed of silt and clay particles which has caused the hydraulic conductivity to be low and, in other words, it causes an impermeable layer to exist in the bed of the river. Another point is related to the speed of the stream. Since, this reach has the lowest speed of stream compared to other reaches; its steep is close to zero.

Previous studies which have been accomplished by Jiang et al. (2015) and Sebok et al. (2014) have somewhat clarified the role of river morphology in the hydraulic conductivity, but in the present research it was attempted present novelty in the methods 
section, especially a Rising Head test method was added with the advanced instrument, and most importantly, the morphological properties of the river and their impact on the $\mathrm{K}_{\mathrm{v}}$ were studied. Moreover, the role of straight and meandering reaches in the entire river along the whole path from upstream and downstream was considered

This study indicates that the special stream morphologies have caused bed forms that relate to erosion and deposition of channel at each test reach. Those different erosion and deposition patterns resulted in different sediment distributions and spatial variability for $\mathrm{K}_{\mathrm{v}}$ values at each test reach (Fig. 7), while the erosional side can probably have greater grain size contrast due to depositional conditions. These are the reasons for hydraulic conductivity variability and the spatial distribution patterns. In fact, the steep of the streambed can be considered as one of the factors leading to the erosional changes in the sediments of the river.

The consistent distribution of the composing materials of the river in the upstream and due to the fact that they approach to each other in the midstream, but in the downstream, especially in the meandering reach of Ghorbanabad (Reach B), this distribution is not consistent and these changes on the shape of the river have led to irregular changes in $\mathrm{K}_{\mathrm{v}}$. In addition, it has caused the distribution of particles to be mixed with sand, as illustrated in the image. In other words, due to the existence of silt and clay, the streambed has changed into an impermeable bed with a very low $\mathrm{K}_{\mathrm{v}}$. Erosion and deposition in of sediments in the meandering reaches $\mathrm{D}$ and $\mathrm{F}$ have led to a higher difference in their hydraulic conductivity.

It should be also noted that, this study attempted to cover the whole streambed so upstream, middle stream and downstream samples, which were selected. The result showed Beyer as the best predictor, however, other formulas might have been the best if all streams had not been selected. On other words, if only downstream sampling with its fine sediments (silt and clay) had been selected, slitcher formula might have been the best. Since, this formula is the strongest in fine sediments. Overall, to have better generalization to all such alluvial rivers (starting from mountain then releasing to plain and/or sea), six reaches were selected.

Due to the selected river morphology, being mostly coarse sediments, Beyer and USBR were more successful in predicting Ks. That is, rivers' fine sediments in downstream were fewer than coarse ones in the whole streambed.

The meticulous pints which is obvious in the present research is related to the fact that hydraulic conductivity difference relative to the estimation of experimental formals is located at downstream and upstream of the rover. So, this fact is highly essential due to the special morphology of the riverbed within this range, in which the bed sediments consisted of coarse grains. In the Future studies, the selected ranges considering whether the region is located in downstream or upstream should be scrutinized independently due to the critical role of $\mathrm{d}_{10}$ factor for estimating the hydraulic conductivity of the riverbed.

\section{Conclusion}

In this study, an in-situ permeameter test method was conducted using both falling and rising-head methods to determine the spatial variability in streambed. The $\mathrm{K}_{\mathrm{v}}$ in a 36-km stream reach in Ziyarat River, located in Golestan Province, Iran, was studied. Collectively, the data from 189 measurements at 6 test reaches were analyzed. There were two different stream morphologies: straight reach and meandering reach. The 
results showed that the difference in the $\mathrm{K}_{\mathrm{v}}$ of meandering reaches was more than the straight reaches, and this difference shows a change in the morphology of the river in these reaches as a result of erosion and deposition. To put it simply, the morphologic changes in the meandering reaches have caused evident changes in the streambed which have, eventually, led to the erosion and deposition of sediments and fluctuations in the values of $K_{v}$.

The $K_{v}$ distributions in the straight reach show that the $K_{v}$ values are greater in the center of the river. The analysis showed that the significance level was less than 0.05 , which is an indication that the two variables are statistically related and have a linear correlation. The distributions of morphologies in streambed from each test reach along the Ziyarat River indicated that the stream morphology is a key variable which affects erosional and depositional conditions and bed forms. The erosional and depositional stream hydrologic processes winnowed the sediments and mobilized the sand and other particles contained in the streambed to form deposits of different grain size.

Streambed hydraulic conductivity may be related to the grain size. The results of grain size analysis showed that the average grain size distribution of streambed sediments in each right, central, and left side of the section in the downstream (Ghorbanabad Reach) have significant differences, especially in the meandering reach of the downstream.

Due to the dynamic sedimentation and scouring processes in the streambed, $\mathrm{K}_{\mathrm{v}}$ showed higher temporal variability $-0.5 \mathrm{~m}$ below the streambed surface occurred in a relatively stable environment. The significant difference between the $\mathrm{K}_{\mathrm{v}}$ of streambed in the upstream and downstream stems from the form of the sediments composing the streambed such that with an increase in the silt and clay in the downstream, a layer with low impermeability is formed. In addition, the $\mathrm{K}_{\mathrm{v}}$ obtained from the two straight and meandering reaches in downstream had a significant difference whereas the same corresponding data were different from each other in the upstream and midstream. Therefore, the effect of the river morphology on $\mathrm{K}_{\mathrm{v}}$ is evident. This indicates that in a meandering stream, more measurements are necessary for the thorough characterization of hydraulic parameters than in a straight stream.

Indeed, the importance of $\mathrm{d}_{10}$ factor relation with hydraulic conductivity cannot be ignored due to the key role of extremely fine particles in the riverbed, including slit and clay. Especially, the afore-mentioned relation is evident within the meandering reaches throughout the river and downstream regions. Moreover, the prediction of hydraulic conductivity using the experimental formulas for data validation was highly affected when the capability of the each experimental formula within upstream to downstream was tested in terms of direct and meandering reaches. The findings obtained for the present article will be useful for other rivers incorporating the similar morphological properties whose bank originates from mountain of steep slope and finally it reaches to see after passing through a plain.

Declarations. There is not any conflict of interest.

\section{REFERENCES}

[1] Boano, F., Camporeale, C., Revelli, R., Ridolfi, L. (2006): Sinuosity-driven hyporheic exchange in meandering rivers. - Geophysical Research Letters 33(18). 
[2] Cardenas, M. B., Wilson, J. L., Zlotnik, V. A. (2004): Impact of heterogeneity, bed forms, and stream curvature on subchannel hyporheic exchange. - Water Resources Research 40(8).

[3] Chen, X. (2004): Streambed hydraulic conductivity for rivers in south-central Nebraska. JAWRA Journal of the American Water Resources Association 40(3): 561-573.

[4] Chen, X. (2005): Statistical and geostatistical features of streambed hydraulic conductivities in the Platte River, Nebraska. - Environmental Geology 48(6): 693-701.

[5] Chen, X., Burbach, M., Cheng, C. (2008): Electrical and hydraulic vertical variability in channel sediments and its effects on streamflow depletion due to groundwater extraction. - Journal of Hydrology 352(3-4): 250-266.

[6] Cheng, C., Song, J., Chen, X., Wang, D. (2011): Statistical distribution of streambed vertical hydraulic conductivity along the Platte River, Nebraska. - Water Resources Management 25(1): 265-285.

[7] Datry, T., Lamouroux, N., Thivin, G., Descloux, S., Baudoin, J. M. (2015): Estimation of sediment hydraulic conductivity in river reaches and its potential use to evaluate streambed clogging. - River Research and Applications 31(7): 880-891.

[8] Dong, W., Chen, X., Wang, Z., Ou, G., Liu, C. (2012): Comparison of vertical hydraulic conductivity in a streambed-point bar system of a gaining stream. - Journal of Hydrology 450: 9-16.

[9] Genereux, D. P., Leahy, S., Mitasova, H., Kennedy, C. D., Corbett, D. R. (2008): Spatial and temporal variability of streambed hydraulic conductivity in West Bear Creek, North Carolina, USA. - Journal of Hydrology 358(3-4): 332-353.

[10] Gordon, N. D. (2004): Stream Hydrology: An Introduction for Ecologists. - John Wiley and Sons, Chichester.

[11] Hvorslev, M. J. (1951): Time Lag and Soil Permeability in Ground-Water Observations. - US Army Corps of Engineers, Vicksburg, MI.

[12] Jiang, W., Song, J., Zhang, J., Wang, Y., Zhang, N., Zhang, X., Long, Y., Li, J, Yang, X. (2015): Spatial variability of streambed vertical hydraulic conductivity and its relation to distinctive stream morphologies in the Beiluo River, Shaanxi Province, China. Hydrogeology Journal 23(7): 1617-1626.

[13] Kasenow, M. (2002): Determination of Hydraulic Conductivity from Grain Size Analysis. - Water Resources Publications, Littleton, Colorado.

[14] Koch, J. C., McKnight, D. M., Neupauer, R. M. (2011): Simulating unsteady flow, anabranching, and hyporheic dynamics in a glacial meltwater stream using a coupled surface water routing and groundwater flow model. - Water Resour Res 47(5).

[15] Levy, J., Birck, M. D., Mutiti, S., Kilroy, K. C., Windeler, B., Idris, O., Allen, L. N. (2011): The impact of storm events on a riverbed system and its hydraulic conductivity at a site of induced infiltration. - Journal of Environmental Management 92(8): 1960-1971.

[16] Leopold, L. B. Wolman, M. G. (1957): River Channel Patterns, Braided, Meandering and Straight. U.S. - Geological Survey Professional Paper 282-B.

[17] Lopez, O. M., Jadoon, K. Z., Missimer, T. M. (2015): Method of relating grain size distribution to hydraulic conductivity in dune sands to assist in assessing managed aquifer recharge projects: Wadi Khulays dune field, western Saudi Arabia. - Water 7(11): 64116426.

[18] Min, L. L., Yu, J. J., Liu, C. M., Zhu, J. T., Wang, P. (2013): The spatial variability of streambed vertical hydraulic conductivity in an intermittent river, northwestern China. Environ Earth Science 69: 873-883.

[19] Nowinski, J. D., Cardenas, M. B., Lightbody, A. F. (2011): Evolution of hydraulic conductivity in the floodplain of a meandering river due to hyporheic transport of fine materials. - Geophys Res Lett 38.

[20] Sebok, E., Duque, C., Engesgaard, P., Bøgh, E. (2013): Anisotropy of streambed sediments of contrasting geomorphological environments and its relation to groundwater discharge. - In: EGU General Assembly Conference Abstracts 15. 
[21] Sebok, E., Duque, C., Engesgaard, P., Boegh, E. (2014): Spatial variability in streambed hydraulic conductivity of contrasting stream morphologies: channel bend and straight channel. - Hydrological Processes 29(3): 458-472.

[22] Song, J., Chen, X., Cheng, C., Wang, D., Lackey, S., Xu, Z. (2009): Feasibility of grainsize analysis methods for determination of vertical hydraulic conductivity of streambeds. - Journal of Hydrology 375(3-4): 428-437.

[23] Song, J., Chen, X., Cheng, C., Wang, D., Wang, W. (2010): Variability of streambed vertical hydraulic conductivity with depth along the Elkhorn River, Nebraska, USA, Chinese. - Science Bulletin 55(10): 992-999.

[24] Vukovic, M., Soro, A. (1992): Determination of Hydraulic Conductivity of Porous Media from Grain-Size Composition. - Water Resources Publications, Littleton, Colorado. 